\title{
RUPTURAS E CONTINUIDADES NA POLÍTICA SOCIAL CHILENA*
}

\author{
PILAR VERGARA
}

O governo militar chileno impôs uma politica social restritiva que subordinou os objetivos distributivos às metas de crescimento e estabilidade da economia. O governo democrático que o sucedeu afirmou reiteradamente que um de seus objetivos fundamentais é a consolidação de uma economia de livre mercado, aberta para o exterior, baseada na empresa privada e na liberalização do sistema financeiro e câmbios internacionais. Defendeu, adcmais, a tese de que uma economia capitalista de livre mercado não é incompatível com uma maior igualdade social. Daí ter definido como o propósito fundamental da sua gestão compatibilizar o crescimento econômico com uma melhoria das condições distributivas, juntamente com um claro compromisso de aliviar a extrema pobreza que afeta uma elevada percentagem dos chilenos. Isso é considerado uma condição básica para a consolidação e estabilidade a longo prazo das instituições democráticas no país. Com esse propósito colocou-se em marcha uma estratégia distributiva de orientação diferente mas complementar da estratégia de crescimento.

Até que ponto existe uma ruptura na política social do novo governo relativamente ao governo anterior? Qual é a capacidade que o modelo econômico de livre mercado e a política social atualmente vigente demonstraram para conciliar as metas de crescimento econômico e graus crescentes de igualdade social? Responder a estas e outras questões constitui o objetivo deste trabalho.

Na primeira seção faz-se uma breve descrição dos principais traços da estratégia econômico-social neoliberal adotada pelo governo militar e de seus resultados mais importantes. Sem essa revisão prévia das heranças problemáticas, assim como das condições estruturais favoráveis

* "Ruptura y continuidad en la politica social del gobiemo democratico". Tradução de Amélia Cohn. 
que a administração anterior legou ao governo democrático, é impossível avaliar o alcance e o significado dos elementos de continuidade e/ou ruptura do modelo atualmente vigente. Torna-se também impossível compreender inteiramente os dilemas e desafios que o governo democrático foi levado a enfrentar, e a natureza e significação das opções adotadas.

$\mathrm{Na}$ seção seguinte são descritas as principais características do modelo econômico e social atualmente em curso, seus objetivos fundamentais e os desafios a que deve responder, incluindo as restrições econômicas e institucionais, e também as oportunidades que o atual governo herdou para a implementação de uma estratégia econômico-social capaz de compatibilizar o crescimento da economia com uma maior equidade social. A seção termina avaliando o modelo de bem estar social que se foi configurando durante os primeiros dois anos de recuperação democrática, suas similitudes e diferenças com o vigente sob o governo militar que saiu, e sua capacidade de conduzir em direção a graus crescentes de igualdade social, compativeis com a consolidação das instituições democráticas no país. Finalmente, a partír da análise anterior e das principais tendências detectadas, na última parte do trabalho encontram-se algumas conclusões e uma reflexão sobre os principais desafios que se apresentam para a ação social do Estado.

\section{O GOVERNO MILITAR E A EXPERIÊNCIA NEOLIBERAL}

\section{A Política Econômica}

Como é sabido, o governo militar reverteu as tendências econômico-sociais imperantes por várias décadas no Chile: reduziu drasticamente o papel de intervenção do Estado, impôs severas contrações ao gasto público social e promoveu a liberalização dos mercados e do comércio exterior e câmbios internacionais, impondo desse modo a supremacia do livre mercado e a subordinação da atividade econômica interna aos fluxos financeiros internacionais. Concomitantemente, desmantelou as estruturas políticas e sindicais por meio das quais as classes populares haviam logrado expressar suas demandas e pressionar por seus interesses.

A reestruturação da economia, a implantação de sucessivos programas ortodoxos de estabilização durante a década dos setenta e os choques externos, que empobreceram o conjunto da economia nacional, produziram uma acentuada deterioração das remunerações, ao mesmo tempo que as políticas macroeconômicas recessivas contraíram drasticamente 0 gasto público destinado a fins sociais e levaram o desemprego aberto e a pobreza a 
níveis sem precedentes na história do país. No início da década de 80 a crise da dívida e a conseqüente transferência de recursos para o exterior, juntamente com uma nova regressão nas condições macroeconômicas e distributivas puseram fim ao otimismo imperante nos círculos oficiais, segundo $o$ qual a economia havia entrado num caminho de crescimento acelerado que poderia ter dado inicio ao tão ansiado ciclo distributivo. A aplicação de uma política de ajuste restritivo forçou uma deterioração adicional das remunerações, novos cortes no gasto social e uma nova alta das já elevadas taxas de desemprego (Tabela 1). Uma condução econômica mais pragmática a partir de 1984 permitiu uma progressiva recuperação da economia e, mais adiante, um crescimento sustentado com uma inflação moderada. Os progressos no âmbito social, todavia, foram escassos, sem que no fim da década se houvesse recuperado sequer os níveis históricos.

Tabela 1. PIB por habitante, inflação, investimento, divida externa, desemprego e remuneraçōes - 1970, 1980 - 90.

\begin{tabular}{ccccccccc}
\hline Ano & PIB/HAB & $\begin{array}{c}\text { Taxa de } \\
\text { Inflaxão }\end{array}$ & $\begin{array}{c}\text { Taxa } \\
\text { de } \\
\text { Invest. }\end{array}$ & $\begin{array}{c}\text { Div. Ext. } \\
\text { milhōes } \\
\text { em US\$ }\end{array}$ & $\begin{array}{c}\text { Taxa de } \\
\text { Desemprego } \\
(\text { a) }\end{array}$ & \multicolumn{2}{c}{$\begin{array}{c}\text { Salários Reais } \\
(1970=100)\end{array}$} \\
\cline { 7 - 8 } & & & & & & & $\begin{array}{c}\text { Média } \\
\text { Salários }\end{array}$ & $\begin{array}{c}\text { Renda } \\
\text { mínima }\end{array}$ \\
\hline 1970 & 100.0 & 36.1 & 20.2 & 3.123 & 5.9 & 100.0 & 100.0 \\
1980 & 116 & 17.6 & 17.6 & 11.207 & 16.9 & 89.4 & 112.7 \\
1981 & 121 & 19.5 & 19.5 & 15.591 & 15.1 & 97.4 & 117.9 \\
1982 & 102 & 15.0 & 15.0 & 17.159 & 26.1 & 97.7 & 116.6 \\
1983 & 99 & 12.9 & 12.9 & 18.037 & 31.3 & 87.0 & 91.6 \\
1984 & 104 & 13.2 & 13.2 & 19.659 & 24.7 & 81.6 & 80.1 \\
1895 & 105 & 14.8 & 14.8 & 20.529 & 22.0 & 83.2 & 74.6 \\
1986 & 109 & 15.0 & 15.0 & 20.829 & 17.3 & 84.9 & 69.6 \\
1987 & 113 & 16.5 & 16.5 & 20.660 & 13.9 & 84.7 & 64.0 \\
1988 & 119 & 17.0 & 17.0 & 18.960 & 11.0 & 90.3 & 66.4 \\
1989 & 129 & 18.6 & 18.6 & 17.520 & 8.6 & 92.0 & 73.8 \\
1990 & 130 & 19.5 & 19.5 & 18.576 & 8.6 & 93.7 & 78.8 \\
\hline
\end{tabular}

Fonte: Banco Central, Contas Nacionais, Instituto Nacional de Estatísticas (INE), JADRESIC (1986).

(a) Inclui programas de emprego de emergência PEM e POJH.

\section{A Política Social}

\subsection{As "modernizações".}

As orientações neoliberais materializaram-se não só em reformas da estrutura econômica mas também da institucionalidade social vi- 
gente no país por várias décadas. O mercado foi expandido para todos os setores e âmbitos da sociedade, até convertê-lo no mecanismo de organização da sociedade em seu conjunto.

Com efeito, junto com a redução do gasto social, promoveu-se a retirada sistemática do Estado dos setores sociais, por meio da privatização dos serviços e da estruturação de uma nova institucionalidade social, completamente submetida às leis do mercado competitivo. Com esse propósito, a partir do final dos anos 70 e começo dos 80 foi dado impulso a um amplo plano de reformas - as denominadas "modernizações sociais" - que transferiram para o mercado e a iniciativa privada a tarefa de prover os bens e serviços sociais antes prestados pelo Estado, deixando que o mercado se encarregasse de regular 0 acesso a essas prestações. Por meio dessas reformas buscava-se promover a criação e expansão de um sistema privado de serviços sociais de alto nível, segundo o qual aqueles que têm poder aquisitivo suficiente financiam com seus próprios meios as atenções sociais que antes recebiam do Estado, prevalecendo um critério de correspondência entre o quanto se contribui para o sistema e as prestações recebidas.

O Estado reservou para si somente a responsabilidade de atender aos setores de menores recursos, que carecem de capacidade para custear as prestações mínimas que requerem.

A reforma da previdência de 1981 (cujo exame aqui restringe-se aos pontos relevantes para nossos objetivos), que afetou somente o regime de pensões, substituiu o antigo sistema de repartição por um de capitalização individual, que é administrado por entidades privadas: as Administradoras de Fundos de Pensões (AFP)), criadas especialmente com esse fim. O Estado devia limitar-se a regulamentar e fiscalizar a operação do sistema. Nas AFP a pensão por velhice que cada trabalhador recebe é o resultado das contribuições que ele acumula durante sua vida ativa, mais o retorno das inversões realizadas pela entidade à qual está filiado com essas contribuições. A cada trabalhador ativo é facultado escolher livremente entre permanecer nas antigas instituições de pensão (de caráter fiscal ou semi-fiscal) ou mudar para as novas. Foram criados uma séric de estímulos para a mudança: para aqueles que escolheram o novo sistema foi aplicada uma taxa de cotização substancialmente mais baixa que aquelas das antigas instituições estatais, e foi-lhes outorgado um "bônus de reconhecimento" por suas antigas cotizações, o que fez com que a imensa maioria dos trabalhadores (especialmente os de mais alta renda, considerando-se as exigências maiores para filiação às AFP, gerando pensões quase $60 \%$ mais altas nas AFP do que as geradas no antigo sistema) mudasse do antigo para o novo sistema. A consequiência disso foi a passagem 
de vultosos fundos estatais para as AFP que capitalizam os fundos de pensão, com o conseqüente desfinanciamento das instituiçzes públicas de pensão. Assim se explica, de resto, que a reforma da previdência não tenha contribuído para uma solução satisfatória de nenhum dos problemas que afetavam o sistema de seguridade social, nem mesmo para a redução do déficit fiscal. Com efeito, o Estado teve que continuar repassando o mesmo volume de recursos de antes para fazer frente às pensões dos já aposentados - ao que vieram se somar maiores recursos que teve que destinar para o pagamento do "bônus de reconhecimento" àqueles que mudaram para o sistema privado - , ao mesmo tempo que os recursos fiscais para a previdência reduziram-se drasticamente quando esta deixou de receber as cotas dos que mudaram de sistema. No final da década de 80 os recursos acumulados nas AFP eram equivalentes a $25 \%$ do PIB, chegando a ter importantes repercussões sobre os niveis de poupança e investimento.

No campo da saúde, a orientação privatizante expressou-se numa profunda reorganização do antigo Serviço Nacional de Saúde (SNS) e na implantação de um novo sistema, o Sistema Nacional de Serviços de Saúde (SNS), composto por 27 Serviços Regionais, competitivos entre si e administrados de acordo com critérios de rentabilidade privada. $\mathrm{O}$ antigo sistema de financiamento da saúde, baseado em destinações orçamentárias segundo critérios históricos, foi substituído por um sistema de bônus baseado na quantidade dos atendimentos prestados (FAP). Pretendia-se, assim, que os recursos recebidos por cada estabelecimento fossem proporcionais ao montante total de atendimentos prestados, incentivando com isto a competição entre os serviços, já que o usuário escolheria onde ser atendido. Por outro lado, a administração dos consultórios da periferia e postos de saúde foi progressivamente transferida para as municipalidades.

De outra parte, juntamente com a implementação da reforma da previdência promoveu-se o desenvolvimento da medicina privada quando da autorização da criação das Instituições de Saúde da Previdência (ISAPRES). Estas são entidades privadas com fins lucrativos, que oferecem serviços médicos em troca da contribuição obrigatória para atenção à saúde daqueles que as escolhem. As ISAPRES limitam os riscos de saúde que desejam cobrir excluindo os adultos mais velhos, as pessoas de maior risčo relativo e com maior número de dependentes familiares e, tal como nas AFP, exige-se uma renda mínima para poder filiar-se. Nelas os benefícios médicos que cada filiado recebe são proporcionais à sua contribuição econômica. A criação das ISAPRES significou, como no caso das AFP, a transferência de vultosos recursos públicos para o setor privado e uma simultânea redução das já exíguas contribuições que recebia a saúde estatal. 
No final da década passada as ISAPRES captavam cerca de $50 \%$ das cotizações da previdência destinadas a ações de saúde (aquelas que anteriormente eram captadas por instituições públicas) e absorviam $38 \%$ do gasto em saúde do país, enquanto que atendiam somente $12 \%$ da população. Daí o desfinanciamento do setor público de saúde e a persistente deterioração da qualidade das prestações recebidas pelos grupos de baixa renda por ele atendidos, na medida em que este deixou de receber precisamente as cotizações daqueles trabalhadores que aportavam maior quantidade de recursos. Ainda mais, o setor público passou a subsidiar a medicina privada, ao assumir o custo de uma série de prestações que as ISAPRES não cobrem porque não são rentáveis, como o subsídio maternidade $e$ as atividades de prevenção e fomento da saúde.

As reformas institucionais tendentes a reduzir a presença do Estado no setor e a desenvolver um mercado privado para a saúde configuraram, como no setor de previdência, a coexistência de dois sistemas de saúde, que segmentam a oferta segundo a capacidade de pagamento do usuário. Esses dois setores são os que melhor refletem o dualismo que se imprimiu na institucionalidade social como produto da definição do papel subsidiário do Estado e da privatização dos serviços.

No campo educacional a reestruturação do sistema transferiu a gestão dos estabelecimentos fiscais para as municipalidades, que por sua vez podiam transferí-las para entidades privadas. Simultaneamente, modificaram-se os sistemas de financiamento da educação, comprometendo-se o Estado a entregar, tanto para as escolas públicas quanto para as privadas gratuitas que foram criadas, uma subvenção por cada aluno que assiste às aulas. Através desse mecanismo de financiamento buscava-se estimular a expansão do ensino privado e, ao mesmo tempo, promover uma administração dos estabelecimentos públicos segundo critérios financeiros de rentabilidade. No início, a criação de escolas privadas subvencionadas significou a captação, sob a forma de utilidade, de importantes recursos públicos por parte dos agentes privados encarregados da sua administração, o que atuou contra a qualidade do ensino prestado. Posteriormente, o congelamento das subvenções ocasionou uma erósão ainda maior da eficiência e da qualidade do ensino prestado por esses estabelecimentos.

A política habitacional também entregou ao setor privado a tarefa de construir habitações populares, cabendo às instituições públicas financiar as soluções habitacionais das famílias que não dispõem de renda suficiente para procurar por si mesmas uma solução habitacional. Com esse propósito, implantaram-se diferentes linhas de subsídio habitacional que eram outorgadas diretamente ao beneficiário para que este dele fizesse uso adquirindo no mercado sua casa própria. Além de encarregar-se do fi- 
nanciamento, o Estado devia selecionar os beneficiários e fixar normas e procedimentos.

No âmbito do trabalho, em 1979 elaborou-se o Plano de Trabalho, que restabeleceu a negociação coletiva, ainda que restrita a empresas individuais, e referida unicamente aos trabalhadores do setor privado. Simultaneamente, foi autorizada a formação de mais de um sindicato por empresa e concedido o direito de lock out ou fechamento temporário de empresas aos empregadores.

\section{$2.2 \mathrm{~A}$ "rede social"}

Simultaneamente à implementação das "modernizações" sociais o governo militar colocou em prática uma série de intervenções sociais seletivas, orientadas para favorecer grupos sociais específicos da população, que se encontravam à margem da ajuda do Estado e que não estavam em condições de satisfazer suas necessidades mais essenciais. Por meio delas buscava-se focalizar nos setores de extrema pobreza parte substancial do gasto social, evitando "infiltraçðes" indevidas deste para os grupos restantes. A "rede social" criada com esse propósito e definida pelo governo militar como o principal instrumento de erradicação da pobreza crítica constituiu, depois das "modernizações", o segundo pilar fundamental da política social do governo militar.

Essa concepção sobre as funções sociais do Estado materializouse na implementação de diferentes linhas de ação no âmbito da previdência social. Em particular, o Subsídio Único Familiar (SUF) destinado à população de escassos recursos menor de 18 anos sem proteção de seguro social, e as Pensões Assistenciais(PASIS), dirigidas aos velhos e inválidos em extrema pobreza sem seguro social; o Programa de Alimentação Complemen$\operatorname{tar}$ (PNAC) e o Programa de Alimentação Escolar (PAE); o Programa de Jardins de Infância da Junta Nacional de Jardins de Infância (JUNJI) e o Programa de Atenção Pré-Escolar do Ministério da Educação, dentre outros.

Esses programas sociais de subsídios focalizados na pobreza crítica eram implantados por meio de modalidades e instrumentos inovadores especialmente concebidos para identificar de forma a mais rigorosa possível as famílias que requeriam atenção prioritária. Dentre eles, a Ficha de Estratificação Social - ou Ficha CAS - era a mais importante. Os programas deviam ser executados de forma descentralizada, radicando-se nas municipalidades as principais responsabilidades de sua aplicação e controle (Vergara, 1990; Raczynski, 1991).

Os benefícios distribuídos pela "rede social", contudo, revelavam-se claramente insuficientes para satisfazer as necessidades mínimas 
de scus beneficiários, e tanto seu montante como sua qualidade apresentaram uma tendência decrescente ao longo de todo o periodo militar. Por outro lado, é preciso ter em conta que a luta para erradicar a extrema pobreza por meio dos programas da "rede social" deu-se no âmbito de uma política econômica restritiva, que mantinha os gastos sociais fortemente deprimidos, e que favorecia a concentração da renda, a queda do emprego e o aumento da pobreza absoluta.

No entanto, com todas as suas limitações e em que pese o valor reduzido - e decrescente - dos subsídios, a rede social logrou compensar parcialmente a queda nos níveis de renda e consumo da população beneficiária, impondo com isto barreiras para seu maior empobrecimento. Mas se deve levar em conta também que, ao não vir acompanhada de uma expansão, mas sim de uma marcada contração dos recursos destinados a esses propósitos, a focalização do gasto social nos grupos de maior pobreza ocorreu às expensas dos recursose benefícios sociais que os estratos de renda média e média baixa recebiam do Estado. Conseqüência direta disto foi a exclusão e o empobrecimento de parte considerável desses setores que, não dispondo de uma renda suficiente para se inscrever no sistema privado, deixava de receber os bens e serviços essenciais que antes o Estado lhes provia.

O gasto público nos setores sociais experimentou uma forte contração durante todo o governo militar, com a única exceção da seguridade social. Isso não se explica por uma melhoria dos benefícios que esta distribui, mas sim pela magnitude dos recursos que o governo teve que destinar anualmente para financiar o déficit originado pela reforma de 1981 (Tabela 2). Em contrapartida, no final do governo militar o gasto nos demais setores sociais situava-se ainda muito mais abaixo dos niveis alcançados nas duas décadas anteriores.

Também as políticas macroeconômicas aplicadas, associadas à legislação trabalhista viesada contra os interesses dos trabalhadores, contribuíram para aumentar substancialmente a desigualdade distributiva. A taxa média de desemprego do periodo foi de $18 \%$, triplicando com isto a taxa dos anos 60. As remunerações reais caíram substancialmente, situando-se em 1989 ainda cerca de 8\% abaixo dos níveis de 1970 (Tabela 1). Coerentemente com a evolução das remunerações e do emprego, entre início da década de 70 e fins da década de 80 , ocorreu uma deterioração distributiva persistente. Explica-se, assim, que nos anos 70 e 80 , em que pesem os subsídios distribuídos pela "rede social", houvesse um incremento significativo - e não uma redução - do número de famílias afetadas por situações de pobreza crítica (Raczynski, 1982).

A informação disponivel para a Grande Santiago evidencia uma queda sistemática da participação da renda familiar na renda total de $25 \%$ das 
Tabela 2. Gasto público social per capita ( $\$$ de 1985).

\begin{tabular}{rrrrrrrrr}
\hline Ano & Educação & Saúde & $\begin{array}{c}\text { Previdência } \\
\text { Social }\end{array}$ & Habitação & Outros & Total $\begin{array}{c}\text { Índice } \\
(1970=100)\end{array}$ \\
\hline 1970 & 11.773 & 6.438 & 24.359 & 4.941 & 271 & 47.782 & 100 \\
1974 & 9.401 & 5.577 & 14.509 & 6.416 & 345 & 36.248 & 76 \\
1975 & 7.441 & 4.321 & 14.765 & 3.662 & 106 & 30.296 & 63 \\
1976 & 7.995 & 4.036 & 14.601 & 2.707 & 276 & 29.576 & 62 \\
1977 & 9.290 & 4.366 & 16.698 & 3.034 & 545 & 33.934 & 71 \\
1978 & 9.774 & 4.829 & 19.970 & 2.836 & 466 & 37.875 & 79 \\
1979 & 10.695 & 4.754 & 22.308 & 3.541 & 567 & 41.865 & 88 \\
1980 & 10.441 & 5.302 & 23.216 & 3.519 & 573 & 43.051 & 90 \\
1981 & 10.844 & 4.814 & 26.974 & 3.482 & 473 & 46.587 & 97 \\
1982 & 10.953 & 5.049 & 31.079 & 2.442 & 367 & 49.890 & 104 \\
1983 & 9.276 & 4.017 & 28.830 & 2.022 & 558 & 44.703 & 94 \\
1984 & 8.967 & 4.244 & 28.729 & 2.362 & 489 & 44.791 & 94 \\
1985 & 8.899 & 4.096 & 26.299 & 3.241 & 469 & 43.004 & 90 \\
1986 & 8.371 & 4.002 & 25.391 & 3.036 & 491 & 41.291 & 86 \\
1987 & 7.418 & 3.970 & 24.916 & 3.333 & 478 & 40.115 & 84 \\
1988 & 7.690 & 4.434 & 25.081 & 3.727 & 497 & 41.429 & 87 \\
1989 & 8.727 & 5.620 & 26.665 & 2.523 & 549 & 44.113 & 92 \\
\hline
\end{tabular}

Fonte: Cabezas, 1988.

familias de menor renda, enquanto que o quintil das mais altas rendas aumentou sua participação relativa (Tabela 3). Por outro lado, a evidência disponivel sobre a pobreza no país revela que entre 1970 e 1987 a proporção de familias cuja renda era insuficiente para satisfazer suas necessidades mais prementes cresceu de $17 \%$ para $38 \%$, o que se traduziu no final do período na existência de mais de 5 milhões de pessoas que viviam nessas condições. As taxas de analfabetismo aumentaram significativamente durante esse periodo e a taxa de escolaridade em 1989 foi $6 \%$ inferior à de 20 anos antes. Verdade que alguns indicadores sociais revelaram uma trajetória favorável, como é o caso das taxas de desnutrição e mortalidade infantis, a esperança de vida ao nascer e a matrícula no ensino básico. Ainda que não seja o caso de analisar aqui as causas do comportamento desses indicadores, o certo é que no fundamental ele obedeceu a uma decisão do governo militar de concentrar nessas áreas os minguados recursos sociais disponíveis a fim de melhorar esses índices, permitindo mostrar internacionalmente resultados bem-sucedidos noâmbito social.

Em sintese, ante à redução do gasto destinado para fins sociais a proposta neoliberal sugeria focalizar os minguados recursos estatais disponiveis na população mais necessitada. Por sua vez, esta proposta estava estreitamente vinculada a outra, de privatização dos serviços sociais, aos quais o acesso está restringido à população de mais altas rendas e nos quais prima um critério de correspondência entre o que o usuário paga e os serviços que recebe. 
Tabela 3. Distribuição em lares ordenados segundo quintis de renda, Grande Santiago - 1969, 1978 e 1988 (porcentagem sobre o total)

\begin{tabular}{lccc}
\hline \multicolumn{1}{c}{ Quintil } & 1969 & 1978 & 1988 \\
\hline I (inferior) & 7.6 & 5.2 & 4.4 \\
II & 11.7 & 9.3 & 8.2 \\
III & 15.3 & 13.5 & 12.7 \\
IV & 20.6 & 21.0 & 20.1 \\
V(superior) & 44.5 & 51.0 & 54.6 \\
\hline Total & 100.0 & 100.0 & 100.0 \\
\hline
\end{tabular}

Fonte: INE. Encuesta de Presupuestos Familiares 1969, 1978, 1988.

A criação e consolidação da institucionalidade social imposta pelas reformas privatizadoras com relação aos programas da "rede social" contribuíram para configurar um modelo dual de bem estar social, que segmentou a sociedade chilena entre, de um lado, setores protegidos pelo sistema de seguridade social - a grande maioria filiada ao sistema privado de serviços sociais - e de outro, uma ampla massa de grupos excluidos, conformada pelos trabalhadores por conta própria, subempregados, desempregados e classes médias empobrecidas, que viram acentuar sua desproteção social em áreas que tradicionalmente eram atendidas pelo Estado. As consequiências regressivas do dualismo que caracteriza o modelo de bem estar viram-se agravadas na medida em que as entidades privadas não se multiplicaram nem expandiram de forma paralela, mas às expensas dos programas e recursos estatais; vale dizer, mediante um sistemático desvio de recursos destes últimos para a área privada. Em conseqüência disto, e dos drásticos cortes ocorridos no gasto social, tem-se o desfinanciamento das instituições públicas de bem estar, o que erodiu severamente a qualidade dos bens e serviços que estas oferecem e se fez sentir no acesso dos mais pobres a seus benefícios.

Na prática, as propostas de privatização e focalização condizentes para conformar o modelo dual de bem estar social de que falamos não constituem senão uma combinação dos tipos de Estados de Bem Estar que Titmus (1968) em sua tipologia denominara "residual" e "meritocrático". De acordo com o primeiro, as políticas estatais devem intervir somente quando falham os mecanismos do mercado, com o propósito de integrar todos aqueles que não possam fazê-lo por via do emprego e do salário. Essa intervenção é concebida como seletiva e transitória - ainda quando possa ser de longa duração - até que tais mecanismos logrem cumprir seu papel. O segundo baseia-se na posição do individuo no mercado de trabalho e, portanto, os benefícios sociais que recebe dependem do 
mérito, do esforço e da produtividade de cada um: cada um escolhe no mercado os serviços que deseja e deve pagar por eles. É a combinação destes dois tipos na experiência chilena que, ao dar origem a sistemas segmentados em função da capacidade de pagamento dos usuários, configura um modelo global de bem estar de caráter dual, que fragmenta a sociedade e reproduz, e mesmo aprofunda, as desigualdades sociais imperantes.

Apesar da retórica anti-estatista do neoliberalismo e da primazia outorgada ao setor privado na provisão dos serviços sociais as antigas instituições estatais de bem estar social não chegaram a ser desmanteladas. $\mathrm{Na}$ prática, manteve-se a responsabilidade estatal de atender a aqueles setores da população protegidos pela seguridade social cuja renda não lhes permite inscrever-se nas entidades privadas. De fato, os neoliberais não lograram desmantelar nem privatizar os serviços estatais de educação e saúde, por exemplo. Houve somente um desmantelamento parcial e seletivo de algumas instituições tradicionais do antigo Estado de Bem Estar.

Mas também as modalidades de funcionamento dos serviços públicos tradicionais sofreram profundas transformações tendentes a submeter sua gestão a critérios de rentabilidade privada: impuseram-se princípios de auto-financiamento do investimento social, sistemas tarifários para os usuários dos serviços e critérios de recuperação de custos. Em virtude desses princípios, também os usuários dos serviços estatais deviam pagar pelas atenções que recebiam - com exceção, e certamente, dos grupos de maior pobreza - , que por sua vez eram proporcionais, em quantidade e qualidade, à magnitude de sua contribuição econômica. Nesse sentido é possivel afirmar que parte importante das instituições do antigo Estado de Bem Estar foi conservada, ainda que suas modalidades de funcionamento tivessem sido modificadas, ao submetê-las a uma lógica mercantil similar à imperante no sistema privado: tal como neste último, estabeleceu-se uma ligação entre a renda do usuário, a contribuição econômica que este faz ao sistema, e os benefícios que recebe dele.

É certo que, se bem os efeitos de longo prazo da contração do gasto público social e de uma institucionalidade social dual como a mencionada tenham um alcance que nenhum indicador pode refletir adequadamente, durante as quase duas décadas de governo militar houve uma deterioração distributiva persistente e um aprofundamento da já aguda heterogeneidade estrutural. Como vimos, o retrocesso experimentado pelos salários do setor operário e a redução dos gastos sociais, por exemplo, viram-se refletidos numa progressiva deterioração na distribuição do consumo (Tabela 3).

Por outro lado, a escassa evidência empírica disponível para esse período traduz uma acentuação da heterogeneidade estrutural, com 
seus conseqüentes impactos sobre as disparidades econômicas e sociais. Com efeito, a modernização contemplou somente uma fração limitada dos chilenos. Enquanto as empresas rurais e urbanas que conseguiram sobreviver às reformas estruturais e as recém-criadas aumentaram sua produtividade e atingiram um grande dinamismo, outros setores ficaram à margem, como é o caso dos pequenos produtores dos diferentes setores da economia e os trabalhadores por conta própria, que tiveram que continuar operando sem o apoio do Estado, e com niveis de produtividade e rendas inferiores àqueles vigentes 20 anos antes. Decorre disto que sob a modemização de alguns setores se escondia a existência de vastos segmentos da força de trabalho que permaneciam marginalizados da modernidade, e que tiveram que subsistir com niveis de renda muito baixos. $O$ mesmo se pode dizer de amplos segmentos das camadas médias, cujos níveis de renda e emprego também foram afetados pela reestruturação da economia e pela aplicação de políticas de ajuste recessivas, e que tambćm ficaram desprotegidos da ação social do Estado. Tudo isto refletiu-se numa crescente informalização das relações de trabalho: no final da década passada, não mais que $45 \%$ da força de trabalho estava cotizando junto ao sistema de previdência, enquanto que, por outro lado, a filiação de trabalhadores às AFP e às ISAPRES se expandia sistematicamente.

\section{O DESAFIO DA TRANSIÇÃO DEMOCRÁTICA}

\section{O Modelo de Livre Mercado}

Ao se iniciar em 1991 a recuperação da democracia, o novo governo do Presidente Aylwin herdou um sistema de organização econômica que não pretendia modificar. No modelo de economia capitalista aberta que prevalecia nesse momento, o Estado havia perdido o papel de protagonista no processo de crescimento, no controle dos mercados e no comércio exterior, e se viu significativamente debilitado em sua capacidade de decidir sobre o processo de investimento, limitando-se a suas funções de formulação de políticas macro-econômicas e à geração de regras gerais no interior das quais devem atuar os agentes econômicos e o mercado, assim como o marco de estabilidade capaz de estimular os investimentos e o crescimento.

É evidente, todavia, que a modernização não abrangia o conjunto da sociedade: no final dos anos oitenta as remunerações médias eram inferiores às de 1970 , a taxa de investimento mantinha-se ainda muito abaixo dos níveis históricos (inferiores a 16\% do PIB), e o crescimento da 
produtividade per capita ainda não superava o $1 \%$ anual. Em outras palavras, ao finalizar a gestão do governo militar ainda subsistia uma elevada proporção de chilenos marginalizados da modernização.

Por outro lado, o setor externo registrava um prolongado e crescente déficit, que havia sido financiado com endividamento externo durante um longo período de tempo e que, ao iniciar-se a transição democrática, representava uma pesada carga para a economia chilena.

Entretanto, a herança neoliberal havia deixado algumas condições estruturais favoráveis para um crescimento com estabilidade, o que representa, sem dúvida, uma singularidade do caso chileno. Diferentemente do que ocorria $\mathrm{em}$ outros países da região, quando o governo democrático assume, as principais reformas estruturais e institucionais haviam sido em sua maioria realizadas, os desequilibrios macro-econômicos no fundamental encontravam-se sob controle e, apesar de um duro processo de ajuste estrutural, o país havia iniciado uma curva de crescimento com inflação moderada e contas fiscais equilibradas - se bem que graças a um gasto fiscal que havia permanecido reprimido por quase duas décadas - e contava com a existência de uma nova geração de empresários que revelava um grande dinamismo e modernidade na gestão de suas empresas.

Associada a esses traços do sistema econômico, a situação social caracterizava-se por graves deficiências: profundas desigualdades distributivas, fortes tensões sociais acumuladas e uma dívida social que afetava um percentual alto de chilenos. O Estado havia reduzido progressivamente seu papel na atenção às necessidades insatisfeitas dos grupos afetados por situações de pobreza aguda, e que normalmente não têm acesso aos mercados e às oportunidades de emprego formal, e inclusive neste terreno, o valor dos subsidios que os beneficiavam havia caído substancialmente.

Quando o novo governo assumiu havia um amplo consenso sobre revalorizar o papel do mercado e dos preços frente ao predominio que tradicionalmente teve o Estado na alocação dos recursos, assim como também a liderança que o setor privado havia assumido no processo de acumulação e no aumento das exportações. Mesmo assim, aceitava-se sem discussão a necessidade de manter-se os equilibrios macroeconômicos sob controle e de assegurar ao governo a capacidade de levar adiante uma política macroeconômica que evitasse possiveis ondas inflacionárias, convencidos que estas desestimulavam os investimentos, dificultam o crescimento da economia e provocam a curtíssimo prazo efeitos regressivos na distribuição da renda. Havia um consenso também sobre a importância de tornar permanentes as principais conquistas econômicas da administração anterior, se bem se reconhecesse a necessidade urgente de superar suas mais graves deficiências, especialmente no âmbito social. 
Paralelamente à revalorização do mercado e dos preços houve uma revalorização da democracia como forma de organização política, uma vez que havia se generalizado um amplo consenso no sentido de que a estabilidade e consolidação de um regime democrático no país requeriam uma preocupação decidida do Estado em assegurar uma maior equidade social e condições de vida aceitáveis para as maiorias empobrecidas, ainda quando este último fator requercsse um horizonte de tempo mais longo. Partia-se da conviç̧ão de que as enormes disparidades entre os êxitos alcançados no plano econômico e uma situação social caracterizada por agudas desigualdades tinham suas origens na combinação de políticas econômicas concentradoras com políticas sociais excludentes e ineficazes, e que isto se revelava incompatível com uma democracia estável. Daí que, se não se modificasse esse estado de cơisas e sem que se criassem as condições políticas, econômicas e institucionais que permitissem compatibilizar um alto crescimento econômico com graus crescentes de igualdade social, não seria possível consolidar as instituições democráticas no país, nem evitar que a médio prazo surgissem sérios problemas de governabilidade, que pudessem debilitar a capacidade de ação governamental e erodir o funcionamento normal do sistema democrático, levando por terra tudo que se havia avançado.

Recolhendo esses consensos, o governo democrático propôs-se a não reverter o modelo de economia abcrta, competitiva e regida pelos mercados herdado do governo anterior. Pelo contrário, afirmou seu forte compromisso com a economia de livre mercado, e inclusive deu uma série de passos no sentido de aprofundá-la. Entre outros, foram mantidas a orientação exportadora, a atitude de abcrtura para a o investimento estrangeiro e foi aperfeiçoada a internacionalização da economia, mediante a proposta ao Congresso de uma baixa adicional das tarifas, aprovada por unanimidade. Foram também firmados acordos de livre comércio e convênios de complementação econômica com outros países latino-americanos; criaram-se novos incentivos para os investimentos estrangeiros e foram adotadas medidas que facilitavam os investimentos de chilenos no exterior. Por outro lado, a política econômica continuou outorgando especial prioridade para o controle da inflação, para a manutenção dos equilíbrios macro-econômicos, e para o financiamento adequado do gasto social, a fim de evitar que se gerassem pressões inflacionárias que pudessem terminar em estancamento e numa distribuição da renda ainda mais regressiva que a inicial. Nessa linha, durante 1990 foi dada seqüência às políticas de ajuste iniciadas pelo governo anterior com o propósito de eliminar os desequilíbrios macro-econômicos que ainda subsistiam.

Transcorridos dois anos e meio de governo democrático a economia mostrava êxitos indiscutiveis. Em 1991 foram alcançadas as metas 
de inflação e crescimento que haviam sido propostas: a produção cresceu mais de $5 \%$, cifra muito superior aos $2 \%$ registrado em 1990, e a inflação atingiu $18 \%$ em comparação a $27,3 \%$ do ano anterior. O setor externo registrou também um ano muito favorável: a balança comercial apresentou um superávit próximo de 500 milhōes de dólares e as reservas internacionais cresceram 1,3 bilhão de dólares. Os investimentos estrangeiros continuaram ocorrendo em montantes crescentes, e as taxas de desemprego, depois da alta experimentada durante o primeiro ano de governo, baixaram em 1991 para cerca de 5,3\%. Durante 1992 a economia chilena apresentou outro ano de elevado crescimento - que é estimado em cerca de $10 \%$ inflação declinante $-12, \%$-, recuperação do investimento (aproximadamente $20 \%$ do PIB) e o nível de emprego mais elevado das últimas décadas, além da solidez nas contas externas.

\section{A Política Social}

Se para o novo governo o modelo econômico de livre mercado devia ser mantido, o esforço distributivo, depois da regressividade da experiência neoliberal, devia descansar fundamentalmente numa política social progressiva. Com efeito, as autoridades do governo sustentaram reiteradamente que o objetivo fundamental de sua gestão era enfrentar o desafio de conciliar o crescimento de longo prazo com uma melhoria, mesmo que lenta, da distribuição da renda e das condiçōes de vida dos setores mais pobres, tudo isto numa situação de estabilidade macroeconômica. Requisitos fundamentais para alcançar esses propósitos distributivos consistiriam, de um lado, no estabelecimento de uma estratégia de negociação entre os principais agentes econômicos, sociais e políticos inclinados a buscar acordos negociados para os problemas de emprego e remunerações e, por outro lado, numa reforma tributária que trouxesse recursos para o desenvolvimento de uma política de expansão do gasto social, embora dentro das margens permitidas pelo financiamento adequado do esforço social.

Em outras palavras, o governo partia da premissa da possibilidade de lograr um crescimento econômico sustentado no âmbito do próprio modelo capitalista de desenvolvimento adotado pelo governo militar, simultaneamente com uma maior equidade social, via acordos negociados que permitissem um aumento das remunerações e do emprego e uma reativação da função social do Estado orientada para os setores de extrema pobreza.

Como se verá mais adiante, no entanto, a estrutura institucional e os modos de operação do sistema de bem estar social impostos pelas re- 
formas neoliberais — as "modernizaçōes" e a "rede social" — foram mantidos sem modificações mais profundas que pusessem fim ao seu caráter dual e a seus impactos excludentes.

Não se pode esquecer que a gestão do governo democrático herdou importantes restrições econômicas, políticas e institucionais, que reduziram sua possibilidade de manobra para desenvolver uma política distributiva mais enérgica, com ênfase no combate à pobreza e à marginalidade social. De um lado, encontrava-se a magnitude dos obstáculos econômicos que se opunham a uma resposta eficaz: entre outros, o peso da dívida externa acumulada e a depressão do gasto social, que havia se mantido estável por muitos anos. De outro, as restrições de longo prazo enfrentadas pelo financiamento do setor público originadas, entre outros fatores, pelo déficit da previdência (que atinge cerca de $10 \%$ do PIB e consome metade do volume destinado pelo Estado para o financiamento da seguridade social), pelo endividamento público provocado pela crise de 19821983 e pelas operaçס̄es de resgate do sistema financeiro, que fizeram com que o Estado assumisse as perdas provocadas pela crise (Marcel, 1991).

A situação herdada na esfera social não era mais promissora. Basta considerar a magnitude das carências básicas acumuladas e a herança de problemas sociais não resolvidos no passado. Tudo isto, ademais, ocorria no contexto de uma situação macroeconômica particularmente adversa para os setores de menor renda - taxas elevadas de desemprego e sub-emprego, queda dos salários reais, etc. -, o que permite explicar a magnitude das tensões sociais que se haviam acumulado e as expectativas de melhoria das condições de vida que se haviam forjado quando o novo governo assume o poder.

Existiam ainda restrições institucionais, que reduziam os graus de liberdade disponíveis para adotar uma política de gasto social mais expansiva. Dentre elas a autonomia do Banco Central na definição das políticas monetária e cambial, além das "amarras" legais decretadas pelo regime militar pouco antes de o novo governo assumir, e que delimitavam estreitamente os seus marcos de ação. Por outro lado, a fragilidade dos equilíbrios macroeconômicos básicos e a necessidade de mantê-los sob controle para evitar qualquer surto inflacionário e uma nova queda na já insuficiente taxa de investimento também limitavam a autonomia das políticas estatais.

Foi nesse contexto que o governo democrático articulou sua política social. Definiu quatro princípios orientadores que deviam marcar uma ruptura com a estratégia de desenvolvimento social do período precedente: equidade, solidariedade, integralidade e participação social. Não obstante, como se verá, as restrições objetivas do sistema e a necessidade 
de lograr um financiamento adequado do gasto social, juntamente com a manutenção do modelo de bem estar social herdado do governo anterior, contribuíram para que esses princípios, em muitos aspectos, tenham mantido sua vigência mais no nível do discurso do que na prática efetiva do governo através de sua ação social.

As primeiras grandes tarefas às quais foi dada prioridade neste sctor foram duas: a Reforma Tributária de 1990, destinada a financiar uma expansão do gasto social, e a reforma da legislação trabalhista. A aprovação desses projetos no Parlamento foi possivel graças à estratégia de negociação adotada pelo governo entre empresários, trabalhadores e partidos de oposição, e ao consenso que se havia formado no país em torno da necessidade de melhorar-se as condições de vida dos setores mais empobrecidos.

Em virtude do denominado "acordo de referência" entre trabalhadores, empresários e governo, a reforma trabalhista permitiu restabelecer alguns dos direitos legítimos dos sindicatos e estabelecer uma legislação trabalhista mais eqüitativa ao permitir negociar os benefícios do crescimento e eliminar os aspectos mais regressivos consagrados no Plano Trabalhista do governo anterior em matérias tais como salários mínimos, pensões, reajuste de remunerações do setor público, contrato de trabalho e estabilidade no emprego, negociação coletiva e direito de greve.

Contudo, e em que pese o inegável impacto distributivo da estratégica de negociação, esta não abrangeu o conjunto da sociedade, ficando seus efeitos em boa medida encapsulados nos setores trabalhistas que dela participaram e, portanto, sem que seus efeitos se fizessem sentir sobre aqueles que possuem uma inserção precária no mercado de trabalho, tais como os trabalhadores temporários e por conta própria, os que se vinculam às atividades de pequenas empresas e os desocupados - a maioria deles indigentes -, e que nem puderam participar nas negociações relativas a matérias que lhes afetam diretamente, como é o caso da fixação do salário mínimo, das normas que incidem sobre suas possibilidades de obter emprego ou o aumento do gasto social.

Os recursos provenientes da reforma tributária, por sua vez, possibilitaram um aumento do gasto social sem provocar desequilíbrios fiscais. Isto constitui sem dúvida um dos principais elementos de ruptura da atual política social com relação ao governo anterior. Com efeito, rompendo com a tendência vigente durante as quase duas décadas, a maior arrecadação dos recursos fiscais permitiu definir uma política de gasto social. Apesar de esses recursos não terem superado $2 \%$ do PIB, eles permitiram aumentar a contribuição do orçamento fiscal para os programas sociais em $17,4 \%$ em 1990, com relação ao gasto inicialmente orçado pelo governo militar para esse mesmo ano. 
Por outro lado, o governo democrático deu seqüência ao outro pilar fundamental da política social do governo militar: a "rede social" dirigida para os grupos de maior pobreza, sem que se tenha alterado fundamentalmente seu caráter assistencialista e compensatório.

Criou-se, ademais, um novo instrumento de ação social: o Fundo de Solidariedade e Investimento Social (FOSIS), com o objetivo de financiar projetos que beneficiem os grupos mais carentes. É definido como um instrumento complementar das políticas e programas que emanam dos ministérios sociais. Seus recursos estão basicamente dirigidos para financiar iniciativas sociais voltadas para a melhoria das condições de vida das comunidades mais pobres e para outorgar apoio integral à micro-empresa urbana, aos pequenos produtores rurais e à pequena mineração artesanal, para que estes possam aumentar sua produtividade e competir com êxito no mercado.

Até agora, todavia, os recursos canalizados pelo FOSIS representaram uma proporção pouco significativa do gasto destinado para fins sociais. Em conjunto, os desembolsos destinados ao financiamento dos projetos desta entidade em 1990-1991 não chegaram a representar nem 1\% do gasto fiscal social (Raczynski, 1992). Em que pese haver ativado múltiplos projetos inovadores e participativos, a insuficiência de recursos impediu este órgão de cumprir o objetivo para o qual fora criado: converter-se na principal ferramenta do novo governo para combater a extrema pobreza.

\section{Resultados e Impactos Distributivos}

Os resultados da política econômica durante os primeiros dois anos e meio de governo democrático no que diz respeito a emprego e remunerações, demonstraram que ao se realizar uma politica econômica eficiente pode-se também fazer simultaneamente uma política social que gere condições favoráveis para os investimentos e a promoção de um crescimento sustentado e estável.

Com efeito, o crescimento da economia registrado entre $1990 \mathrm{e}$ 1992 teve importantes efeitos sobre o mercado de trabalho, permitindo integrar significativos contingentes desocupados da força de trabalho. Depois da queda de $0,8 \%$ experimentada pela ocupação total em 1990 como conseqüência do ajuste econômico destinado a pôr fim à tendência inflacionária que vinha se produzindo desde 1989, esta se recupera nos anos subseqüentes para terminar em $1992 \mathrm{com}$ um aumento de $3,5 \%$, o que resultou numa taxa de desemprego de $4,5 \%$, a mais baixa dos últimos trinta anos. A isto somou-se uma mudança significativa na qualidade e composição do emprego, ao concentrar-se a geração de novos postos de trabalho 
principalmente nos setores modernos da economia (PREALC, 1991; MIDEPLAN, 1992). Em outras palavras, a geração de novas ocupações registrada em 1991-1992 como conseqüência do maior nível de atividade econômica desses anos viu-se acompanhada de uma tendência à modernização da estrutura ocupacional, como expressa a diminuição relativa dos empregos informais com relação ao período anterior. Estima-se, assim, que em 1992 a ocupação formal urbana havia aumentado em $4,4 \%$, enquanto a informal urbana em somente 3,7\% (MIDEPLAN, 1992, b). Este mesmo fenômeno ocorreu também no percentual da força de trabalho que contribui para o sistema previdenciário, que aumenta de $41 \%$ em 1989 para 45,3\% em 1992.

O salário mínimo aumentou substancialmente: entre 1989 e 1992 apresentou um aumento real de $26 \%$. Isto, somado ao fortalecimento da capacidade de negociação dos trabalhadores, combinados ambos os fatores com a queda do ritmo inflacionário, redundou num aumento das remunerações. Nesse mesmo período elas crescem, em termos reais, a uma taxa média anual de 3,6\%. Além da geração de novos empregos, esse processo também se vê refletido no aumento da participação das remunerações no PIB, que teria aumentado de $37,1 \%$ em fins de 1990 para $3,8 \%$ no final de 1992 (MIDEPLAN, 1992, b). Também os níveis de renda dos $20 \%$ mais pobres da população aumentaram sua participação na renda total — de 13,5\% em 1991 para 14,1\% em 1992 - somente pelo efeito da menor taxa de inflação. Segundo essa vertente, $40 \%$ da população mais pobre teve um aumento de $5 \%$ em sua renda, enquanto os $40 \%$ mais ricos uma redução de $1 \%$ na sua renda real. Como resultado desse processo e da constante expansão do emprego, estima-se que o percentual de pobres na população total diminuiu, entre 1990 e 1992 , de $40,1 \%$ para $33,4 \%$.

Esse resultado estaria confirmando que uma política antiinflacionária ativa contribui efetivamente para impedir que se reduzam as rendas reais dos grupos mais vulneráveis. Cabe assinalar que as cifras anteriores não incluem o gasto público social em saúde, educação e habitação. Considerando-se esse gasto, os níveis de bem estar dos grupos de menores rendas com certeza exibiriam uma taxa de crescimento superior à média.

Não obstante isso, a evidência disponível também revela que o impacto do crescimento econômico sobre a expansão dos níveis de emprego e renda dos segmentos mais pobres da população apresenta limitações. Com efeito, em que pese haver induzido um aumento dos níveis de renda de toda a população, a política econômica do governo democrático não logrou alterar de modo significativo a distribuição de renda. A participação do quintil de menor renda no total da renda mantém-se praticamente 
inalterada ou, no melhor dos casos, apresenta aumentos somente marginais de 4,2\% em 1990 para 4,8\% dois anos depois. Por sua vez, a participação do quintil de maiores rendas mantém-se levemente acima de 53\%: nesse mesmo biênio cai somente de 55,1\% para 53,2\% (MIDEPLAN, 1992). Isto confirma uma vez mais que as forças do mercado, ainda que num contexto de crescimento do produto e de desaceleração inflacionária, não logram trazer uma contribuição efetiva para uma maior equidade social, na medida em que não contribuem para reduzir as desigualdades sociais.

Com certeza o valor do salário mínimo, que se reveste de uma importância crucial para os trabalhadores mais pobres, seja como mecanismo de defesa de suas remunerações ou como piso de referência na sua fixação, contribui para explicar parte não desprezível dos resultados acima. Apesar de este ter aumentado substancialmente, seu montante atual se situa ainda muito abaixo do que seria necessário para adquirir uma cesta básica de consumo que permita satisfazer as necessidades mínimas de uma família chilena. Por outro lado, se bem que o dinamismo da economia associado à estratégia de negociação entre empresários e trabalhadores favoreceram a expansão do emprego e das remunerações rcais, as negociações permaneceram restritas aos trabalhadores do setor formal, e que estão protegidos pela seguridade social graças às suas contribuições mensais, excluindo portanto os trabalhadores temporários, por conta própria e do mercado informal, que são exatamente os mais pobres.

Por outro lado, os dados disponíveis indicam que o crescimento econômico, através de seu impacto sobre os niveis de emprego melhora somente a situação dos pobres não indigentes, e não destes, que não vêm melhoradas" sua situação de emprego e renda por meio desse conceito. Apesar de a análise da experiência chilena entre 1990 e 1992 mostrar que as rendas monetárias da população indigente aumentaram, isto deveu-se quase exclusivamente à contribuição dos subsídios monetários outorgados pelo Estado. Isto revela uma outra limitação de uma estratégia de crescimento baseada no livre mercado para realizar uma real contribuição para a redução da pobreza extrema: a inacapacidade do mercado de integrar produtivamente os extremamente pobres e o papel determinante da política social para a subsistência desses setores.

Com certeza esses resultados explicam porque parte considerável dos grupos pobres não indigentes correspondem ao que se denominou "pobres recentes" ou "pobres conjunturais" (Kaztman, 1989); isto é, grupos que se viram empobrecidos em consequiência dos ciclos recessivos e da aplicação de programas de ajuste estrutural e que, se bem apresentassem carência de rendas, não necessariamente exibiam uma deterioração em seus níveis mais permanentes de vida, como na educação e na saúde. 
Dai que, ao se produzir uma reativação econômica que expanda as oportunidades ocupacionais, estes setores logrem integrar-se produtivamente na economia, e abandonar assim a situaçăo de pobreza que os afetava.

Distinto é o caso dos pobres indigentes, que além de não disporem de rendas que lhes permitam uma subsistência mínima, arrastam consigo carências inerciais na satisfação de suas necessidades básicas. Daí carecerem de condições para integrarem-se ao desenvolvimento, ainda que na presença de uma expansão das oportunidades ocupacionais. Com efeito, estes grupos são majoritariamente compostos por jovens sem qualificação e mulheres chefes de familia, assim como por crianças e velhos, que não se integram na produção. Com exceção destes últimos dois grupos, que necessariamente devem receber o apoio do Estado através de ações de politica social específicas que lhes assegurem uma subsistência digna ou, no caso das crianças, que os prepare para sua futura inserção na produção, trata-se de segmentos da população que carecem de uma política de qualificação minima para o trabalho que lhes permita incorporar-se ao mercado de trabalho por seus próprios meios, e escapar assim da situação de miséria que arrastam consigo. Isto abre um amplo espaço, também, para a ação social do Estado no âmbito da capacitação para o trabalho e na geração de mecanismos que permitam a esses setores integrar-se ao desenvolvimento.

O segundo elemento central da política social vem sendo constituído pela expansão do gasto público social financiado com o aumento de recursos propiciado pela Reforma Tributária. Os dados disponíveis sobre a evolução do gasto fiscal social entre 1989 e 1992 mostram que, depois de experimentar uma queda em 1990, este aumenta com taxas elevadas durante os anos seguintes, até alcançar em 1992 o nível mais elevado na história do país. Apesar de o aumento do gasto social ocorrer em todos os setores, ele foi especialmente acentuado na saúde e habitação (Tabela 4).

Os maiores recursos tributários arrecadados - mais os recursos internacionais obtidos - destinaram-se, primordialmente, ao aumento dos

Tabela 4. Gasto Fiscal Social - 1989/1992 (Índice 1989=100)

\begin{tabular}{lccccrr}
\hline Ano & Saúde & Habitação & Educação & Previdência & Outros & Total \\
\hline 1989 & 100.0 & 100.0 & 100.0 & 100.0 & 100.0 & 100.0 \\
1990 & 107.0 & 118.9 & 97.9 & 115.0 & 97.2 & 92.2 \\
1991 & 134.4 & 142.0 & 107.0 & 142.3 & 119.6 & 108.2 \\
$1992^{\mathrm{a}}$ & 161.3 & 159.1 & 115.5 & 128.6 & 129.1 & 120.8 \\
\hline
\end{tabular}

Fonte: MIDEPLAN (1992 a)

(a) corresponde ao orçamento para 1992 
subsidios monetários que favorecem os grupos de menores rendas; particularmente, aos reajustes das contribuiçðes familiares, do subsidio único familiar (SUF) e das pensões mínimas e assistenciais, cujo valor real havia experimentado uma real deterioração durante a administração anterior.

Com efeito, o valor real dessas prestações e do subsidio à aposentadoria aumenta significativamente ao longo de todo o período em estudo. A cobertura destes subsídios, em compensação, não mostra um comportamento uniforme: enquanto o número de contribuições familiares cresce significativamente, as pensões assistenciais concedidas diminuem em 1991 e os SUF concedidos não atingem esse ano os niveis de 1989.

Ao mesmo tempo, os recursos adicionais arrecadados permitiram reforçar o financiamento dos programas de saúde, habitação e educação. Os maiores fundos que foram outorgados ao primeiro setor se destinaram, fundamentalmente, a ampliar a atenção primária e à realização de investimentos em equipamento e em recuperação dos hospitais, que haviam sido abandonados durante o governo militar. Na educação, deu-se início a um programa de melhoria da educação básica e se aumentou a cobertura do programa de alimentação escolar (PAE). Finalmente, no setor habitacional, os benefícios dos seus programas foram estendidos às famílias "ampliadas". Buscou-se, por outro lado expandir a cobertura da ação pública para grupos antes desprotegidos, como é o caso dos jovens desempregados, dos velhos e da mulher chefe de família.

Não obstante, os antecedentes disponiveis sobre os benefícios outorgados nos diversos setores sociais, e em particular os subsídios que fazem parte da "rede social", dirigida para os grupos mais vulneráveis, mostram tendências distintas. Com efeito, apesar de as matrículas nas instituiçōes vinculadas à Junta Nacional de Jardins de Infância (JUNJI) terem aumentado durante todo o período considerado, não acontece o mesmo com os Centros Abertos de INTEGRA, nem com a educação básica sob a responsabilidade do Ministério da Educação, onde a matrícula cai abruptamente em 1992. Como resultado dessas tendências descritas, a cobertura da educação pré-escolar (excluídos os Centros Abertos ) cai levemente entre 1989 e 1991 : de $13,5 \%$ para 13,0\%.

Por outro lado, a quantidade de alimentos distribuídos pelo Programa Nacional de Alimentação Complementar (PNAC) mantém-se praticamente constante durante o período examinado, apesar de terem aumentado os quilos de alimentos distribuídos pelo programa básico voltado para o programa de reforço biomédico, que favorece as crianças e as gestantes nutricionalmente vulneráveis. As rações (café da manhã e almoço) distribuídas pelo Programa de Alimentação Escolar (PAE) nas escolas básicas gratuitas, por sua vez, aumentam significativamente ao longo do 
período estudado. Em 1990 houve ainda um aumento da quantidade energética do programa, com o que a ração completa passou a compreender 1000 calorias diárias (contra 800 calorias anteriores). Também os subsídios habitacionais outorgados experimentaram uma apreciável expansão em 1990 e 1991.

No âmbito da saúde, as cifras disponiveis não apontam uma tendência uniforme, com leves altas no caso de algumas prestações e quedas em outras. O comportamento relativamente medíocre das atenções à saúde proporcionadas pelo setor público provavelmente obedece ao fato de que a grande parte dos recursos adicionais outorgados para a saúde tenha sido canalizado para construção e equipamentos hospitalares.

Em síntese, enquanto os subsídios monetários aumentam seu valor e a maior parte deles expande sua cobertura, os subsídios para os setores da saúde, educação e habitação, particularmente aqueles que beneficiam os grupos de extrema pobreza, exibem uma tendência flutuante, boa parte deles sendo declinante conforme se avança para o final do período em exame. Por outro lado, os benefícios que a "rede" distribui continuam sendo insuficientes, mais ainda se se consideram a magnitude e intensidade da pobreza no país. Em sua imensa maioria, o valor dos subsídios situa-se ainda abaixo do mínimo indispensável para que seus beneficiários possam satisfazer suas necessidades mais elementares e/ou aumentar seus níveis de produtividade e rendas e abandonar assim o circulo vicioso da pobreza do qual são prisioneiros. É fácil compreender então que, mesmo quando numa política de gasto social expansiva como a implementada por essa administração ocorra uma mudança na tendência e direcionalidade da intervenção social do Estado, os aumentos dos gastos tenham se revelado insuficientes para compensar a magnitude das carências básicas acumuladas e, como se verá, em alguns setores é inclusive provável que não logrem compensar os efeitos regressivos de uma institucionalidade dual como a herdada do governo militar, cuja organização e modos de funcionamento foram conservados sem mudanças de fundo.

\section{A Institucionalidade Social}

Grande parte das dificuldades que a política social enfrenta para lograr uma maior equidade social tem origem na institucionalidade social vigente desde o governo anterior, e que continua provocando uma permanente transferência de recursos públicos para as entidades privadas que prestam serviços sociais à população de mais alta renda.

Com efeito, em que pesem os esforços realizados para avançar no sentido de uma maior igualdade social por meio da reforma tributária e 
do aumento do gasto social, a tendência consistiu em consolidar a mesma institucionalidade social dual herdada do governo anterior. De fato, esta tem como apoio a mesma organização institucional dos setores sociais e conserva as mesmas modalidades de financiamento que as reformas neoliberais impuseram durante o governo militar, sem que se tenham introduzido mudanças que atenuem seu caráter excludente e scgmentador da sociedade chilena. Vale dizer, por um lado consolidou-se o sistema privado de serviços sociais financiado pelos grupos de mais alta renda, e cujo acesso é restrito somente a eles; e por outro lado manteve-se um sistema de assistência social compensatória - a "rede social" - com orçamento exíguo, voltado para o atendimento das necessidades mais essenciais dos grupos mais pobres desprotegidos do sistema de seguridade social, e que fornece somente algumas prestações básicas.

Daí não parecer imprudente afirmar que em seus aspectos essenciais o atual modelo de bem-estar social chileno e seu caráter dualista se caracterizam mais por uma continuidade que por uma ruptura com o modelo social imposto pelo neoliberalismo. Mais ainda, tudo leva a crer que suas tendências regressivas e excludentes permanecerão enquanto continue a transferĉncia dos trabalhadores de mais alta renda do antigo sistema estatal para os serviços privados, com a conseqüente transferência de recursos públicos para estes últimos, e a conseqüente deterioração dos recursos de que dispõem os serviços estatais, que atendem à população mais necessitada. Esta situação transforma-se num sério obstáculo para a redução das desigualdades sociais imperantes e para a erradicação definitiva da extrema pobreza no país.

Assim, por exemplo, o sistema previdenciário imposto pela reforma de 1981 permanece sem grandes mudanças que introduzam em seu funcionamento critérios de equidade e solidariedade condizentes com os princípios que supostamente orientam a ação pública, e/ou que compensem os parcos recursos estatais destinados à previdência, e que vão parar nas mãos das entidades privadas.

O sistema do ISAPRES tampouco passou por mudanças de fundo que incorporassem critérios de solidariedade em seu funcionamento. Os recursos que o Estado destina à saúde pública, embora tenham aumentado, ainda não representam muito mais que $1 \%$ do PIB. Mais ainda, parte não desprezível desses recursos continua destinada a subsidiar o sistema ISAPRES, na medida em que o setor público continua assumindo a responsabilidade pelas prestações que essas instituições não cobrem. Com efeito, elas não se mostram dispostas a financiar uma saúde integral para toda a população beneficiária, não outorgam o subsídio maternidade, nem se preocupam com a prevenção e promoção da saúde, tarefas que devem 
ser assumidas pelas instituições de saúde estatais. Por outro lado, dado que os recursos fiscais destinados à saúde e a qualidade dos serviços prestados pelo setor público para a população beneficiária são deficientes, isto constitui um estímulo permanente para a transferência daqueles trabalhadores para as ISAPRES, porque reúnem os requisitos de renda e estabilidade que estas exigem. Isto, por sua vez, provoca uma erosão adicional dos recursos de que dispõem os estabelecimentos públicos — que devem atender a $80 \%$ da população - com o conseqüente impacto sobre a qualidade das atenções prestadas e o acesso dos mais pobres às prestações mínimas que eles requerem. Por sua vez, o sistema das ISAPRES, que cobre atualmente $20 \%$ da população, continua aceitando somente os trabalhadores de mais alta renda (o que lhe permite dispor de uma média de 200 dólares anuais por beneficiário, contra 50 dólares das instituições estatais) e recusando os afiliados de mais alto custo, como é o caso das pessoas mais idosas, das com maior número de encargos familiares, e dos doentes crônicos.

Por outro lado, mantém-se o sistema de financiamento dos serviços públicos de saúde baseado no faturamento por atenção prestada (FAP) e em sistemas tarifários para os usuários. Isso redunda numa alocação dos recursos que privilegia a atenção das patologias próprias dos grupos mais diferenciados, em detrimento das atenções requeridas pelos setores de menor renda.

Na educação básica e pré-escolar, mantém-se o sistema de financiamento através de subvençōes estatais, se bem que o valor destas tenha sido reajustado. No setor de habitação foi dada sequiência à política de subsídios habitacionais iniciada pelo governo anterior, ainda que se tenham introduzido algumas modificaçōes nos seus sistemas de postulação e destinação com o propósito de atenuar as discriminações que afetavam aqueles que não possuem recursos suficientes para acumular a poupança prévia exigida para se postular o subsídio.

Foi mantida também a gestão dos serviços públicos de acordo com critérios financeiros de mercado e rentabilidade privada, com seus previsiveis impactos regressivos sobre os grupos de menor renda.

Em sintese, pode-se afirmar que nos fatos se mantém a dualização no interior da política de bem estar social entre duas linhas de ação com orientaçōes distintas: uma institucionalidade social que assegura o acesso a serviços privados de alta qualidade e livre escolha no mercado para os grupos de mais alta renda, e o assistencialismo e a dependência permanente de subsídios estatais - ainda que insuficientes - para os grupos mais pobres.

Se bem não haja nada a objetar que os setores de mais alta renda financiem com seus próprios recursos os serviços sociais que requerem, 
longe de se complementarem e de se reforçarem uma à outra, essas duas linhas de ação são em muitos aspectos contraditórias entre si, dado que o funcionamento de um modelo dual de bem-estar dessa natureza produz uma contínua drenagem de recursos estatais para as entidades privadas.

\section{CONCLUSÕES E IMPLICAÇÕES}

\section{Função do Estado}

O crescimento da economia durante o governo democrático, juntamente com a diminuição do ritmo de crescimento dos preços, traduziu-se num aumento dos níveis de emprego e de renda de todos os grupos sociais, e em particular dos mais pobres, o que se refletiu numa redução do número de pobres no país. Todavia, a distância entre pobres e ricos não diminuiu. Dos chilenos mais pobres $40 \%$ percebem apenas $14,2 \%$ da renda nacional, enquanto $20 \%$ da população de mais recursos percebem mais da metade dessa renda. É nessa profunda desigualdade na distribuição da renda que reside a raiz da pobreza que ainda penaliza $33,4 \%$ dos chilenos (o que não desqualifica a focalização do gasto social nos grupos mais pobres, mas sugere que ela não é, por si só, uma solução satisfatória para o problema da pobreza). Em consequiência, a resposta à pergunta que nos fazíamos no início (sobre a possibilidade de conciliar as metas de crescimento e equidade nos marcos de uma economia de mercado, aberta e exportadora como a que existe atualmente) não poder ser taxativa. Se bem que a pobreza tenda a diminuir pelos efeitos do crescimento da economia, o mercado por si só não resolve o problema da inequidade: a profunda desigualdade na distribuição da renda mantém-se praticamente sem alterações.

Por outro lado, o crescimento econômico através de seu impacto sobre o mercado de trabalho logrou somente melhorar a situação dos pobres não indigentes. Os indigentes, em compensação, somente viram aumentados seus níveis de bem-estar graças à contribuição dos subsídios monetários do Estado. Estes resultados desmentem uma vez mais a ilusão representada pela antiga tese da "estagnação" distributiva, tão cara ao pensamento neoliberal, segundo a qual a distribuição de renda e a solução dos problemas dos mais despossuídos só pode vir do crescimento da economia e, em conseqüência, da capacidade de "impulsão" dos setores modernos. Ao contrário, eles demonstram que numa economia de livre mercado o crescimento não tende, pelo menos a curto e médio prazos, a integrar os grupos de maior pobreza aos frutos do desenvolvimento. 
Esta capacidade do mercado de integrar produtivamente os mais pobres num prazo de tempo eticamente aceitável fortalecendo ainda mais o emprego e os salários, expõe uma vez mais a função indiscutível de o Estado se responsabilizar do propósito de integrar os grupos atualmente excluídos dos mercados e das oportunidades de emprego formal, intensificando sua ação nas áreas de educação, saúde e de apoio à pequena empresa e à capacitação para o trabalho, tanto daqueles jovens e trabalhadores que não logram incorporar-se aos mercados de trabalho, quanto daqueles que se encontram atualmente integrados no processo de desenvolvimento, mas que não logram niveis de produtividade e renda que lhes permitam ter acesso a níveis satisfatórios de bem-estar social.

Em que pesem os esforços realizados até agora para expandir o gasto social, os recursos destinados para tais fins não estiveram à altura dos problemas que se pretende resolver. As políticas assistenciais que outorgam subsídios monetários para a população mais pobre são imprescindíveis, pelo menos no curto e médio prazos, mas não bastam. Mais ainda, é inevitável que isto se traduza numa ação estatal compensatória que, além de não lograr uma superação definitiva da extrema pobreza, contribui muito pouco para conciliar o crescimento econômico com uma maior equidade social. Por outro lado, a focalização dos recursos destinados para fins sociais nos grupos mais despossuídos, com tudo de positivo que possa ter, revelou-se insuficiente para compensar as carências básicas acumuladas. Mais ainda, no final do período analisado, a cobertura dos subsídios não monetários para a população mais pobre se mantém, ou mesmo decresce, para alguns setores sociais, atingindo em alguns casos niveis inferiores aos do último ano do governo anterior. As insuficiências do gasto social também vêm à tona na situação crítica do setor da educação, nas dificuldades de acesso aos serviços de saúde e na baixa qualidade da atenção prestada pelos estabelecimentos estatais à população com recursos escassos.

\section{Legislação Trabalhista}

Os baixos salários que abrangem um contingente significativo da força de trabalho são os principais responsáveis pela extrema pobreza que ainda subsiste no país. Sua erradicação requer um aumento das remunerações e melhoria das condições de trabalho dos grupos mais necessitados, para o que se torna imprescindivel introduzir mudanças na legislação trabalhista vigente, com o propósito de eliminar as restrições que ela ainda consagra, permitindo expandir a negociação coletiva aos setores que atualmente dela não podem fazer uso, particularmente aos trabalhadores temporários e àqueles que trabalham nas pequenas e médias empresas, com o 
objetivo de através desse tipo de negociação conseguirem empregos de melhor qualidade e uma transferência progressiva dos aumentos de produtividade para seus salários.

\section{Eficiência e Impacto Distributivo}

É evidente que as metas de crescimento e estabilidade não podem ser sacrificadas. Fazê-lo significaria enfrentar sćrias dificuldades para continuar estimulando os investimentos e provocaria a curtíssimo prazo efeitos ainda mais regressivos nas condições distributivas. Por isso as políticas sociais a serem adotadas devem contar sempre com o respaldo financeiro adequado que as tome sustentáveis e que não comprometa os equilíbrios macro-econômicos e orçamentários.

Dadas as restrições orçamentárias que inevitavelmente vão acompanhar a politica social e que a impedirão de aumentar substancialmente os recursos canalizados para fins sociais, coloca-se a necessidade inadiável de aumentar a produtividade do gasto social para elevar sua eficiência e seu impacto distributivo.

Neste modelo social vigente existe uma considerável margem para uma racionalização do gasto social que permita liberar recursos para favorecer os mais pobres. Entre eles, a redistribuição do gasto social entre e no interior dos setores para favorecer os mais necessitados; a racionalização da produção e distribuição dos bens e serviços sociais; as modificações na organização dos serviços sociais que permitam superar a atual desarticulação e rigidez que impedem uma condução mais unificada e integrada da política social; e a superação dos problemas derivados da ausência de coordenação entre instituições e programas a fim de evitar duplicações e o conseqüente desperdício de recursos, etc.

A necessidade de racionalizar o gasto social nos conduz a outro problema. Trata-se da reforma do Estado, com tudo o que ela significa em termos da modificação das atuais estruturas administrativas; da modernização e agilização dos mecanismos da gestão pública; de uma efetiva descentralização dos poderes de decisão; da redefinição das responsabilidades do aparato público, do setor privadoe da sociedade civil na provisão dos serviços sociais básicos e da restauração da capacidade do Estado para reorientar o processo de desenvolvimento segundo seus critérios e prioridades.

\section{Institucionalidade Social}

Para além das inevitáveis restrições orçamentárias que acom, panharão a política social, parte considerável das limitações que esta 
última enfrenta para contribuir mais na luta contra a pobreza tem origem no dualismo que continua caracterizando a institucionalidade social sobre a qual se apóia. Isto provoca uma diminuição progressiva dos recursos das instituições estatais que atendem a população mais necessitada, com a conseqüente erosão da qualidade das prestações que esta recebe.

Assim, por mais que se aumentem os recursos destinados ao gasto social e por mais eficiente que seja a sua focalização na população mais necessitada, se não se introduzirem reformas institucionais significativas no modelo dual de bem-estar social definido e cristalizado durante a experiência neoliberal, dificilmente haverá progressos substanciais na redução da pobreza e das desigualdades econômicas e sociais. Essas modificações deveriam dar origem a um novo padrão de políticas sociais, tanto no plano institucional como nas modalidades de operação e financiamento do sistema, que coloquem efetivamente a equidade e a solidariedade como princípios orientadores do desenvolvimento social e revertam os mecanismos reprodutores da desigualdade que derivam das tendências dualistas que predominaram até agora, bem como da sistemática transferência de recursos estatais para as entidades privadas. Cabe lembrar que isso não supõe necessariamente aumentar o tamanho do Estado nem a estatização dos serviços sociais. Supõe, sim, prover o Estado da capacidade política e técnica para definir as orientações fundamentais da estratégia de desenvolvimento econômico e social.

É verdade que a discussão sobre um modelo de bem-estar social mais justo que ao mesmo tempo seja compatível com o modelo de organização econômica não tem nada de simples. Entram aí demasiadas questões técnicas, econômicas e políticas, para não mencionar outros fatores tão decisivos como aqueles relacionados com o contexto internacional. $\mathrm{E}$, dada a envergadura e complexidade da tarefa e as resistências que inevitavelmente deverão ser enfrentadas, é ilusório supor que reformas tendentes a produzir uma alteração radical dos princípios norteadores do atual modelo de bem-estar social encontrarão uma solução fácil. Tampouco é fácil vislumbrar as referências alternativas para as soluções viáveis, capazes de conciliar um sistema econômico eficiente e dinâmico com uma institucionalidade social que assegure graus crescentes de igualdade.

Contudo, um sistema de proteção social que imprima forma institucional ao princípio da solidariedade deveria acionar mecanismos que induzam os extratos de mais alta renda, filiados às entidades privadas que prestam serviços sociais, a aportar recursos, direta ou indiretamente, para o financiamento das prestações básicas que se deve garantir para os mais pobres, de tal forma que pelo menos seja assegurado o acesso a certas prestações básicas universais e comuns a todos os chilenos. Este poderia 
ser o caso, por exemplo, de alguma fórmula de re-estruturação dos atuais sistemas duais e segmentados de serviços sociais e sua substituição por outros, que combinem fórmulas de repartição para prestações mínimas e uniformes para todos, em termos de um direito independente do volume da contribuição individual, com sistemas de seguro para as prestaçб̃es de mais alto custo, que seriam financiadas exclusivamente pelos segurados. Trata-se, em outras palavras, de estabelecer uma cidadania social que assegure a todos certas condições básicas de desenvolvimento biológico, intelectual e de trabalho como fundamento da cidadania política.

PILAR VERGARA é pesquisadora da FLACSO - Programa Chile, em Santiago

\section{BIBLIOGRAFIA}

ARELLANO, I.P. (1979): Politicas sociales y desarrollo. Chile 1924-84. Ediciones CIEPLAN, Santiago.

ARELLANO, J.P. (1989): "La seguridad social en Chile en los años 90", Colección Estudios CIEPLAN 27, dezembro.

BRESSER PEREIRA, L.C., J.M.MARAVALL e A. PRZEWORSKI, (1992): "Economic Reforms in New Democracies: A Social-Democratic Aproach", trabalho apresentado na Conferência sobre "Democracia, mercados y reformas estnucturales en América Latina", organizada pelo Centro Norte/Sur da Universidade de Miami, Buenos Aires, 25 a 27 de março.

CABEZAS. M. (1988): "Revisión metodológica y estadistica del gasto social en Chile: 197086". Notas Técnicas CIEPLAN 114, maio.

FFRENCH-DAVIS, R. (1991): "Desarrollo economico y equidad en Chile: Herencias y Desafios en el retomo a la democracia", Colección Estudios CIEPLAN 31, março.

FFRENCH-DAVIS, R., D.RACZYNSKI (1990): "The Impact of Global Recession and national Policies on Living Standars: Chile, 1973-89", Notas Técnicas CIEPLAN 97 , novembro, $3^{\prime}$ edição.

FLAÑO, N (1991): "El Fondo de Solidariedad e Inversión Social. En que estamos pensando?", Colección Estudios CIEPLAN 31, março.

FOXLEY, A. (1982): Latin American Experiments in Neo-Conservative Economics. University of Califomia Press, Califormia.

GARCIA, A. (1991): "Las orientaciones de la politica social", Colección Estudios CIEPLAN 31 , março.

GURRIERI A., E.TORRES RIVAS (Coords.) (1990): Los años noventa: Desarrollo con equidad?, FLACSO-CEPAL, San José.

HAINDL, E., C.WEBER (1986): "Impacto redistributivo del gasto social", Serie de Investigación, Depto. de Economia, Universidad de Chile.

HAINDL, E. et al (1989): Gasto social efectivo. Un instrumento que asegura la superación definitica de la pobreza critica, ODEPLAN, Universidad de Chile, Santiago. 
IGLESIAS, A. et al (1991): 10 años de historia del sistema AFP. Antecedentes estadisticos 1981-1991. AFP Habitat, Santiago.

MARCEL, M. (1991): "E1 financiamiento del gasto social", Colección Estudios CIEPLAN 31, março.

MARTINEZ, J. e E.TIRONI (1985): Las clases sociales en Chile. Cambio y estratificación, 1970-1989, SUR, Santiago.

MARTINEZ, J. e A. LEON (1984): "La involución del proceso de desarrollo y estructura social", Materiales para Discusión, CED, novembro.

MIDEPLAN (1991): Un proceso de integración al desarrollo. Informe Social 90/91, Ministerio de Planificación y Cooperación, Repulica de Chile, Santiago.

MIDEPLAN (1992a): Avanzando en equidad. Un proceso de integración al desarrollo, 1990-1992, Santiago.

MIDEPLAN (1992b): "Impacto de la politica economica y social en 1991 y estimación para $1992^{\prime \prime}$, mimeo, novembro.

MUÑOZ, O. (1991): "Estado, desarrollo y equidad: algunas preguntas pendientes", Colección Estudios CIEPLAN 31, março.

RACZYNSKI, D. (1991): "La ficha CAS y la focaliación de programas socilaes", Notas Técnicas CIEPLAN 141, Santiago.

RACZYNSKI, D. (1992): "Politicas sociales en Chile: origen, transformaciones y perspectivas", CIEPLAN (mimeo).

SANCHEZ, H.(1990): "Analisis del subsistema de ISAPRES - periodo 1981-1989, en M.I.Romero (ed.): Eficacia y calidad del sistema de salud en Chile", CPU.

TIRONI, E. (1988): Autoritarismo, modernización y marginalidad. El caso de Chile 197389. Editorial Puerta Abierta, Santiago.

TITMUS, R. (1968): Essays on the Welfare State, Allen and Ubwin, London.

VALENZUELA, A. e S.VALENZUELA (Eds.) (1986): Military Rule in Chile: Dictatorship and Oppositions, The Johns Hopkins University Press, Baltimore and London.

VERGARA, P. (1985): Auge y caida del neoliberalismo en Chile, FLACSO, Santiago.

VERGARA, P. (1990): Politicas Hacia la extrema pobreza en Chile, 1973/1988, FLACSO, Santiago. 


\section{RUPTURAS E CONTINUIDADES NA POLÍTICA SOCIAL CHILENA}

\section{PILAR VERGARA}

Até que ponto existe uma ruptura na política social do governo democrático relativamente ao governo do general Pinochet? Até que ponto é possivel conciliar as metas de crescimento econômico e de busca de equidade social em uma economia de mercado? O governo Aylwin conseguiu manter a economia em expansão, o que resultou na criação de empregos e em certa redução do número de chilenos pobres. Os gastos sociais aumentaram em 1990-92 graças à reforma tributária de 1990. Mas nem o puro dinamismo do mercado e nem mesmo uma política expansiva de gasto social têm-se mostrado suficientes para atenuar o caráter dualista e socialmente regressivo do modelo de bem-estar social que emergiu das políticas neoliberais do regime autoritário.

\section{RUPTURES AND CONTINUITIES IN THE CHILEAN SOCIAL POLICIES}

How diferent is the social policy of the Chilean democratic government as compared with Pinochet's government? How much is it possible to conciliate the goals of economic growth and of social equity in a 
market economy? The Aylwin government managed to maintain economic expansion and to increase social expenses. But neither the pure dynamism of the market nor a policy of expanding social expenses have been able to atenuate the dualist and socially regressive character of the welfare model that arose from the neoliberal policies of the authoritarian regime. 